\title{
A FIVE-YEAR DEGREE PROGRAM LEADING TO A BACHELOR OF SCIENCE IN BIOLOGY AND A MASTER OF SCIENCE IN BIOMEDICAL ENGINEERING
}

\author{
C. J. Chuong, K. Nelson, K. Behbehani, R. C. Eberhart \\ Joint Program in Biomedical Engineering \\ The University of Texas at Arlington and \\ The University of Texas Southwestern Medical Center at Dallas
}

\begin{abstract}
The Joint Program in Biomedical Engineering at The University of Texas at Arlington and The University of Texas Southwestern Medical Center at Dallas has joined with the Biology undergraduate department at The University of Texas at Arlington to develop a five year BS/MS dual degree program. This new program is significant in: 1) being responsive to the ever changing environment of biomedical engineering, placing particularly strong emphasis on the life sciences; 2) emphasizing the application of engineering principles to problems which increase understanding in the field of cell and molecular biology; 3 ) providing focused training to meet the demands of a rapidly growing segment of a high-tech industry. This program brings intellectual diversity to our graduate students, intermingling students with strong life science background with the more traditionally trained students with engineering backgrounds. This program is set up for problem-based learning, and may provide a platform to develop a new problem-based curriculum.
\end{abstract}

\section{Introduction}

The Joint Program in Biomedical Engineering at The University of Texas at Arlington and The University of Texas Southwestern Medical Center at Dallas has joined with the Biology undergraduate department at The University of Texas at Arlington to develop a five year BS/MS dual degree program. The program is developed to meet the technical challenges in the biotechnology industry and the demand for uniquely trained manpower. The curriculum provides students with the essentials of both life science and engineering theory, and the tools to enable them to be successful in the biotechnology industry. Students are required to take selected courses from the engineering, life science and liberal art curricula, culminating in a joint MS degree in Biomedical Engineering and a BS degree in Biology. 


\section{Significance}

This new program is significance in that: 1) being a fast track program, it is responsive to the ever changing environment of biomedical engineering with particularly strong emphasis on the life science education; 2) placing emphasis on applying engineering principles to current problems in the rapidly growing field of cell and molecular biology; 3) providing focused training to meet the demands of an important new segment of high-tech industry.

Our current emphasis is on the tissue and cellular engineering area, preparing students for careers in these sectors of the biotechnology and biomedical engineering industries. This program also provides a solid base for those students desiring to enter medical school or to pursue a doctoral degree in biomedical engineering.

\section{Curriculum}

The curriculum of this new program is based upon a strong foundation in undergraduate biology. Students who enroll in this new program take all of the core courses for a standard Bachelor of Science degree in biology. The difference is that all of the major elective courses are replaced with preparatory engineering courses, such as math- up to and including differential equations, and sophomore and junior level engineering foundation courses such as statics and dynamics, thermodynamics, circuit analysis, momentum, mass and heat transfer, etc. During the last three semesters, the courses taken are primarily taken at the graduate level biomedical engineering level. Distributions of disciplines, in terms of semester hours and $\%$ time are summarized in the following table and pie chart:

\begin{tabular}{||l||r|r||}
\hline \hline Disciplines & Semester hr. & $\%$ \\
\hline \hline English & 6 & $4 \%$ \\
\hline Mathematics & 13 & $8 \%$ \\
\hline Physics and Chemistry & 27 & $16 \%$ \\
\hline Biology & 30 & $18 \%$ \\
\hline Anatomy and Physiology & 6 & $4 \%$ \\
\hline Core Engineering & 31 & $19 \%$ \\
\hline Biomed Engineering & 30 & $18 \%$ \\
\hline Other Courses & 24 & $14 \%$ \\
\hline
\end{tabular}

167

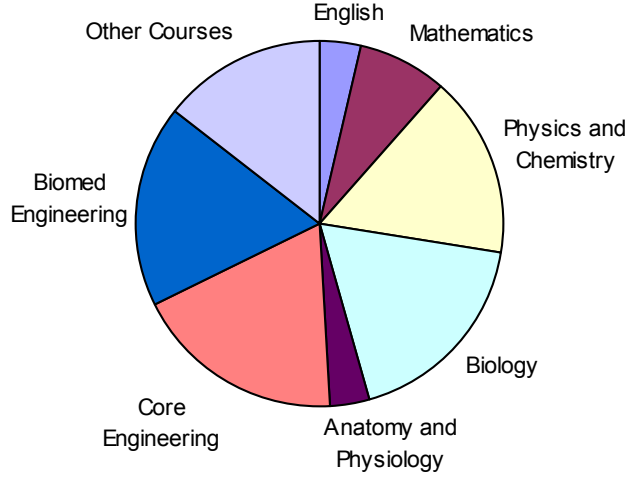

Students in this program also complete the full 37 semester credit hours required for a Master's of Science degree in Biomedical Engineering without any deviation from the standard curriculum.

A primary feature of this new 5-year program is the emphasis on cell and molecular biology, as they pertain to tissue and cell engineering, thus preparing students to enter this exciting. 


\section{Summary}

This program brings diversity to our graduate students, intermingling students with strong life science background with the more traditionally trained students with engineering backgrounds. This program is set up for problem-based learning, and may provide a platform to develop a new problem-based curriculum. Finally, this new program has had the important benefit of attracting more well-qualified students into our BME program.

CHARLES CHUONG

Dr. C. J. (Charles) Chuong is Professor of Biomedical Engineering with research interests in biomechanics and orthopedics.

\section{KHOSROW BEHBEHANI}

Dr. Behbehani serves as Professor and Director of Biomedical Engineering Program at the University of Texas at Arlington. His area of interest is application of signal processing and control theory to biomedical engineering problems. He is a registered Professional Engineering in the State of Texas.

KEVIN D. NELSON

Dr. Nelson is an Assistant Professor of Biomedical Engineering at the University of Texas at Arlington. His areas of interest are biomaterials and tissue engineering.

ROBERT C. EBERHART

Dr. Eberhart is Professor of Engineering in Surgery with the Department of Surgery at the University of Texas Southwestern Medical Center at Dallas. He served as the Director of the Joint Biomedical Engineering Program from 1984 to 2001. His areas of interest are biomaterials and tissue engineering. 